PRF:IJ

VI-2

\title{
Contents
}

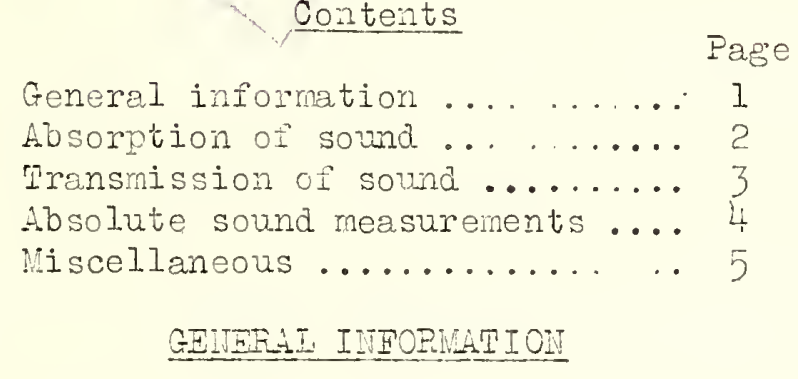

Some of the publications in this list have appeared in the regular series of publications of the Bureau and others in various scientific and tecinical journals. Unless specifically stated, papers are not obtainable from the National Bureau of Standards.

Were the price is stated, the publication can be purchased from the Superintendent of Documents, Government Printing Office, Washington, D. C. The prices quoted are for delivery to addresses in the United States and its temitories and possessions and in certain foreign countries wilich extend the franking privilese. In the case of all other countries, one-third the cost of the publication should be added to cover postage. Remittances should be made eitier by coupons (obtainable from the Superintendent of Documents in sets or 20 for $\$ 1.00$ and good until used), or by checl or money order payale to the "Superintendent of Documents, Govemment Printing Oficell and sent to him with order.

Publications marled "Op" are out of print, but, in general, may be consulted at techical libraries.

For papers in other scientific or technical journals, the name of the journil or of the organization publishing the articie is given in abbreviated form, with the volume nunber (underscored), pase, and year of publication, in the order named. The Bureau can not supply copies of these journals, or reprints of them, and it is unable to furnish information as to their availability or price. They, too, can usurlly be consulted at techical livraries.

Series letters with serial numbers are used to designate Bureav. publications: 
S "Scientific Paper". SI to S329 are "Reprints" from the "Bulletin of the Bureau of Standards". S330 to 5572 were published as "Scientific Eapers of the Bureau of Standards". This series was superseded by the "Bureau of Standards Journal of Research" in 1928.

T "Technologic Faper". TI to T370. This series was superseded by the "Bureau of Standards Journal of Research" in 1928.

RP "Research Paper". These are reprints of articles appearing in the "Bureau of Standards Journal of Researcll" and the "Journal of Researcin of the National Bureau of Standards", the latter being the title of this periodical since July 1934 (volume 13, number 1).

C "Circular".

I. Miscellaneous Fublication".

TNE "Iechnical INews Bulletin".

BMS "Building Materials and Structures" puilication.

Circular cat and supplements, the complete list of the Bureau's publications (1301-1936), is sold by the Superintendent of Documents for 55 cents. Announcement of new publications is made each nonth in the Technical News Eulletin Which is obtainable by subscription at 50 cents per year.

\section{SOLID ABSORETION}

\section{Title}

Series Price

The absorntion of sound at oblique angles of incidence.

Paul R. Hejl, V. I. Chrisler and R. F. Snyder. (1937) RPI49 OP

The measurement of sound absorption. V. I. Chrisler and

… Snyder. (1930) $\ldots \ldots \ldots-\ldots$ RP242

An automatic reverbcration meter for the measurement of

sound absorption. iT. I. Snyder. (1932) - $\ldots$ RP457 OF

Some of tine factors wili afiect the measurenent of sound

absorption. V. I. Chrisler and Catherine E. Willer.

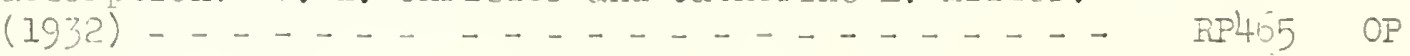

Dependence of sound absorption upon the area and distribution

of tire absorbent material. V. I. Chrisler. (1934) RP7CO $5 \mathrm{c}$

Effect of paint on the sound absorption of acoustic materials. (.1940) - - - . - RPI298 $10 \mathrm{k}$ 
Architectural acoustics. Paul R. Feyl and V. I. Chrisler. (1938) _.....................

Sound absorption coefficients of the more common acoustic materials. Free on apolication to the National Burear of Standirds. (Februry 1941) .......... IC-632

Classification of acoustic materials. Free on application to the National Bureau of Standards. (February 10,41)

New industry - manufacture of sound absorbing material.

(August 1932) . . . . . . . . . . .

The measurement of sound absorption by oscillograph

records. V. I. Chrisler. J. Acoustical Soc. Arn., 1418 (April 1930).

Recent advances in sound absorption measurements. V. I. Chrisler. J. Acoustical Soc. Am., 2, 123 (July 1930).

Measurements with a reverberation meter. V. I. Chrisler and 7 . F. Snyder. J. Soc. Motion Picture Engineers, 18, 479 (April 1932).

\section{SOUID TRAIISIISSIOII}

\section{Title}

Transnission and absorption of sound by some building

materials. E. A. Eckhardt and V. I. Chrisler. (1926)

$\$ 526$

OP

A aiscussion of some of the principles of acoustical insulation. V. I. Chrisler.

Series

Price 
Title

Soundproofing partitions.
Series Price

$\operatorname{TIB} 176$

Frozress in soundproofing of airplane cabins. Air

Cormerce Bul., I, no. 21 (Way 1930).

The sound insulating properties of partition valls (chiesly lath and plaster). E. A. Eckhardt and V. I. Chrisler. Am. Arcinitect, 128, 405 (november 1925).

Sound insulation. V. I. Chrisler. Architecture, 5I, 87 (Feorury 1928).

Sounderoofing apartment houses. V. I. Chrisler. Architectural Forum, 50, 623 (April 1929), 765 (May 1929).

Decreasing noise in airplane cribins. Domestic Air ivews. Serial no. 49 (March 31, 1929).

Sound transmission of materials. V. I. Chrisler. Am. Architect, 138, 32 (Ausust 1930).

Measurement of sound transmission. V. I. Chrisler. J. Acoustical Soc. Am., 1,175 (January 1930).

Reduction of airplare noise. Aeronautics Bul., no. 25 (00tobor 1, 1930).

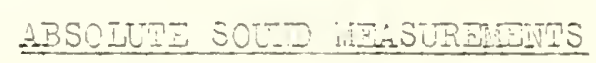

\section{Pitle}

Series Price

fibsolute pressure calibrtions of microhones. R. i. Cook.

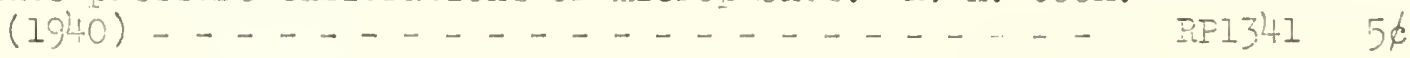

Aosolute pressure colibrstion of microphones. R. K. Cool.

J. Acousticol Soc. Am., I2 (Junutry 1941).

\section{MISCSIINEOUS}

Report olt st on reduction of aimlene moise by use of muftirs. Air Co:merce Bul., 4, no. 12 (Decenber 15, 1532). Reprints available

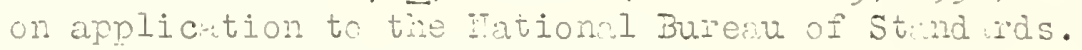

Acousticul work of the rational Bureau of Standrds. Y. I. Chrisler. J. Acoustic: I Soc. Am., I, 79 (October 1935).

Frinciples, proctice nd progress of noise reduction in airolanes. Albert London. Tecimical rotes of Mationcl Adrisory Comittec for Aeronutics ITo. 748 .

Acousticl investigm,tions of Joseph Zenm siewed in 1940. T. F. Snyder. J. Acoustical So A. Am., 12, 58 (July .294C). 